\title{
OZ-DEHYDRATOR
}

石黒設計工務所 石黒綱

産業界における固液分離の工程は重要な部門である が，そこに使用されている機種は必ずしも適正かつ十 分な物とほ言いがたい。また工場廃水処理装置および 上下, 水道浄化装置より発生される污泥については殆 えど脱水未処理にて装置敷地内に放置されている現状 であり, 今後益々の経済発展に伴ない増大するであろ ら。発生污泥执よび污物の完全処理は重大な業務であ る。

\section{連続脱水機 “OZ-DEHYDRATOR”}

これはロールによる加圧脱水機構であるが, 従来の ロール加圧機の種々ある久陥を完全に除去し，合理的 に加圧脱水ができる構造とし, 含水分の多い流動状物 質で從来直接加圧脱水の不可能なものでも連続的に処 理できる。例えば饀粒アルギン酸ソーダ、リン酸アル ミ炭酸カルシニーム, 石灰泥, 上下水道污泥などをポ ンプにより, ヘッドタンクに揚げロータリーバルブに て定量供給する事により連続的にしか子均一な脱水度 が得られる。な和前後の工程がパイパラインコンベヤ 一などにて接続できるので人手をはぶき多大な省力化 となる。

また特殊な濾材を使用しているため 2 3 ミクロン の非常な微粒子の含まれた例えばマグネシューム, カ ルシューム, アルミニューム, 顔料などの水和物の処 理も高度の脱水が得られ, 従って乾燥費用を軽減でき
るため極めて経済的である。

また工場廃液を従来の濾過機などによる脱水が不十 分なため，運搬が困難で，乾燥は更に不経済であるた め, 污泥を敷地内の広い面積に放置されている場合が 多い。このよらな物をさらに十分脱水を行ならことに より飼料, 肥料などの原料となりまたは埋立に利用 できる場合が多い。

本機はこのような比較的脱水の困難とされていた物 質も滑り現象を防止し, 圧縮力を最大限に活用できる ため, 高度の脱水が可能である。なお本機は連続式濾 過および脱水において常に問題となる固型分の剝離は, 特殊な構造により濾面が物理的に伸縮するため固型分 の剥離を容易とし, 同時に目づまりを起こし難い。

また固型分の濃度が極めて低い懸濁液の処理は, 高 分子などの凝集剂を添加し, 凝集反応によりフロック の成長を計り沈降を促進させ, コンセントレーターな ぞにより濃縮, 沈澱スラッジを排出ロータリーバルブ などにより，本機に供給し，濾過脱水を連続的に行な らことができ, 設置面積も極少にてすみ高度の脱水が 得られ有効である。その他特徵として非常に低馬力で 良く, 機構が竪牢に製作し易いため大型化が可能であ り, 挾圧方式であるため圧縮比, 圧縮時的などの脱水 条件が物性に合致した調整が可能であるため“コミ゙” など種々雑多の混合物をも連続的に脱水処理が可能で ある。

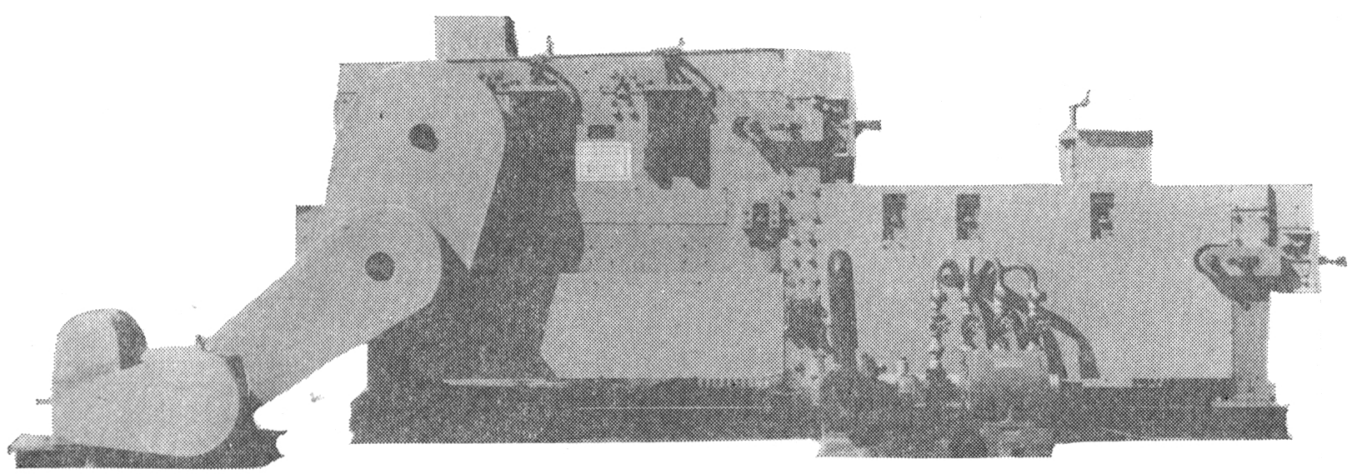


脱水例

\begin{tabular}{|c|c|c|c|}
\hline & $\begin{array}{l}\text { 脱水前 } \\
\text { の水分 } \\
(\%) \\
\end{array}$ & $\begin{array}{c}\text { 脱水後 } \\
\text { の水分 } \\
(\%)\end{array}$ & $\begin{array}{c}\text { 脱水率 } \\
(\%) \\
\end{array}$ \\
\hline 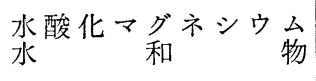 & 90.0 & 40.0 & 92.5 \\
\hline $\begin{array}{l}\text { 水酸化アルミ } \underset{\text { 和 }}{\text { 水 }}=\text { 公 } \\
\text { 物 }\end{array}$ & 92.0 & 45.0 & 97.5 \\
\hline $\begin{array}{l}\text { 水酸化カルシ } \\
\text { 和 }\end{array}$ & 92.0 & 38.0 & 94.8 \\
\hline $\begin{array}{c}\text { 炭酸カルシュ } \\
\text { 和 }\end{array}$ & 80.0 & 35.0 & 86.5 \\
\hline 湿 潤 酸 化 鉄 & 25.0 & 12.5 & 56.0 \\
\hline パルプ工場排水 No. 2 & 99.0 & 55.0 & 98.8 \\
\hline No. 1 & 97.0 & 60.0 & 95.3 \\
\hline 粘土 泥 漿 物 & 92.0 & 30.0 & 96.2 \\
\hline 燐酸アルミ水和物 & - & 48.0 & - \\
\hline 工場排水余剰污泥 & 75.0 & 60.0 & 50.0 \\
\hline 凍結融解後の寒天 & 92.0 & 83.0 & 57.6 \\
\hline 饀 & 90.7 & 63.0 & 82.5 \\
\hline アルギン酸ソーダ & 99.8 & 82.0 & 90.0 \\
\hline 港 粉 粕 & 92.0 & 60.0 & 78.3 \\
\hline アルギン酸抽出残渣 & 94.5 & 76.0 & 81.5 \\
\hline 野 菜 の 搾 汁 & - & 680 & - \\
\hline 蜜柑表皮の搾汁 & 87.0 & 67.0 & 69.0 \\
\hline 製 紙 工場 排水 No. 3 & 96.0 & 47.5 & 96.2 \\
\hline
\end{tabular}

\section{機 械 仕 様}

○本体有効ベルト幅 $500 \sim 1500 \mathrm{~mm}$

駆動馬力 3〜10世

機体寸法 $3800 \mathrm{~L} \times 1030 \sim 2100 \mathrm{~W} \times 1300 \sim 1500 \mathrm{H}$

○吸引ポンプ $1.0 \mathrm{~m}^{3} / \mathrm{min} \sim 10 \mathrm{~m}^{3} / \mathrm{min}$

駆動馬力 $3 \sim 15 \mathrm{P}$

○スラリーポンプ $0.1 \mathrm{~m}^{3} / \mathrm{min} \sim 1.0 \mathrm{~m}^{3} / \mathrm{min}$

駆動馬力 $2 \sim 15 \mathrm{P}$

○薬液ポンプ プランジャ型 $0 \sim 500 \mathrm{cc} / \mathrm{min}$

駆動馬力 $1 / 2 \sim 1 \mathrm{P}$

○定量供給バルブ ロータリーバルブ

$2.5 \mathrm{l} / \mathrm{min} \sim 10.0 \mathrm{l} / \mathrm{min}$

○ヘッドタンク 都度物質に合致した型態, サイズを 採用

○自動制御盤 立 型

機械能力 $100 \sim 300 \mathrm{~kg} / \mathrm{hr}$. (乾物) 対象物により変 る

装置価額 500 万〜 3,000 万

詳しいことは中央区日本橋小舟町 1-2（電 661-8456） 中央技研工業株式会社へ

\section{用}

途

食品工業 農産加工 畜産関係

化学工業 製薬関係 醸造関係

鉱山関係 工場廃水污泥上

下水道污泥 ゴミなどの污物

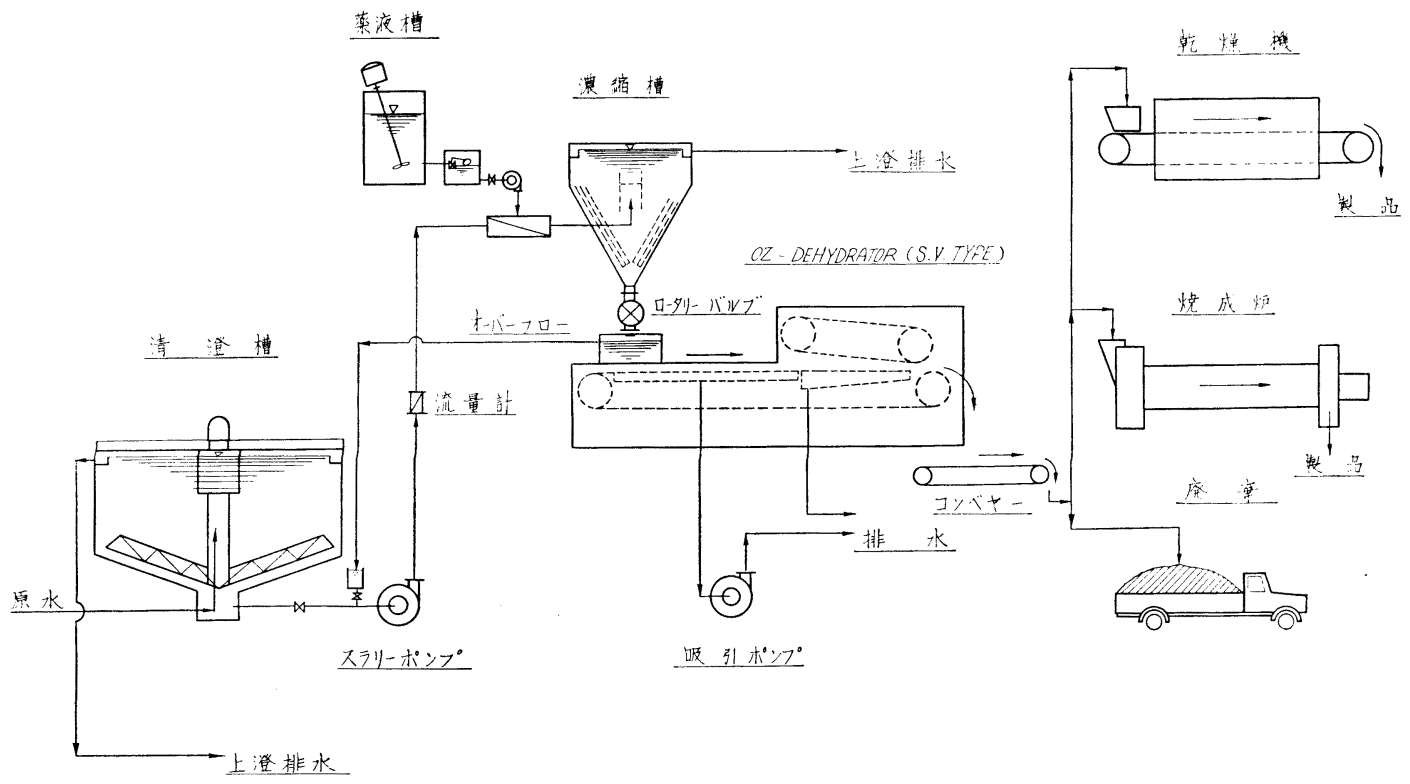

